\title{
SOCIALIZATION OF THE IMPORTANCE OF THE AGENCY'S SPT STRATEGY AND DEVELOPMENT UMKM STRATEGY IN PARUNGPANJANG DISTRICT
}

\author{
Hidayatul Mu`Arifin, Siti Ratna Sari Dewi, Iin Rosini \\ Universitas Pamulang Tanggerang, Indonesia \\ Email: dosen02202@unpam.ac.id,dosen01077@unpam.ac.id,Hafizh_iin@yahoo.com
}

\begin{abstract}
The purpose of this research is to provide an understanding of the making of the Agency's Annual SPT and the development strategy of MSME-IKM and to find out what obstacles are faced during the MSME-IKM Kec Forum. Parungpanjang at the time of making the annual corporate tax return. To achieve this goal, training activities for the preparation of the Agency's Annual SPT were carried out in UMKM-IKM Kec. Parungpanjang. The method used in this research is through training and coaching activities. The data collection method used in this study is a quantitative and descriptive method, namely by reviewing, researching, and providing training and guidance to companies in recording transactions and making annual and periodic tax returns. Thus making the company more effective and efficient in dealing with financial reporting and tax reporting issues. This bookkeeping and recording becomes a very crucial thing because what is recorded or recorded will be the basis for every taxpayer to calculate the amount of tax owed. From the results of this study, financial transactions have not been properly recorded into financial statements, although simple because there are many obstacles in making the annual corporate tax return, one of the factors is that human resources or managers do not understand and understand the recording. and the importance of the company's annual tax return.
\end{abstract}

Keywords: agency annual SPT; UMKM-IKM; development strategy

Received: 2021-09-22; Accepted: 2021-10-05; Published: 2021-10-20

\section{Introduction}

With the development of a country and the increasing industrial world and with the emergence of various competitions and increasingly complex challenges, to cover the necessities of life and to be able to maintain survival, humans must always try. The problem faced by the wider community in Indonesia in general is an economic problem. The government will not be able to work on all aspects of development because it requires a lot of budget, personnel, and supervision. Therefore, entrepreneurship is a development potential, both in number and in the quality of entrepreneurship itself (Pye, 2015).

$\begin{array}{ll}\text { How to cite: } & \text { Mu'Arifin. H., Dewi. S.R.S., \& Rosini,I., (2021) Socialization of The Importance of The Agency's } \\ & \text { SPT Strategy and Development UMKM Strategy In Parungpanjang District, Syntax Idea, 3(10), } \\ & \text { https://doi.org/10.36418/syntax-idea.v3i10.1526 } \\ \text { E-ISSN: } & \text { 2684-883X } \\ \text { Published by: } & \text { Ridwan Institute }\end{array}$


The UMKM-IKM Forum is present in the midst of the association as a forum for the UMKM in the Parungpanjang sub-district which focuses on fulfilling the needs of human life in the culinary field. In addition, this company is also present as a forum to assist the government in providing jobs.

The definition of MSMEs according to Law no. 20 of 2008 concerning Micro, Small and Medium Enterprises Chapter 1 Article 1: Micro-enterprises are productive businesses owned by individuals and/or individual business entities that meet the criteria for micro-enterprises. Small business is a stand-alone productive enterprise, which is carried out by individual or business entity is not a subsidiary of the company owned, controlled, or become a part either directly or indirectly directly from medium or large businesses that meet business criteria small. Medium enterprises are productive economic enterprises that stand itself, which is carried out by individuals or business entities that is not a subsidiary or branch of a company owned, controlled, or become a part either directly or indirectly with a small business or a large business with a total net worth or annual sales results (Lita \& Murwadji, 2019).

The development of technology in the industrial world today causes a company to be required to use technology as the main support for the work of the entity. Computer Accounting is one of the fields of information technology (IT) which is supported by the ability and mastery in the field of accounting. Processing of data into information can be done manually or by using electronic equipment such as computers. So far, the company is still using manual recording by going through training and coaching to help companies record transactions and to help companies make Annual and Periodic SPTs. It is hoped that after this training and coaching the company will record and prepare financial statements and assist the company in reporting and paying taxes in accordance with applicable laws. This is because bookkeeping and recording is a very crucial thing because what has been recorded or recorded will be the basis for every taxpayer (Scheer, 2012).

According to the KUP Law Number 16 of 2009 Article 1 number 29, bookkeeping is a recording process that is carried out regularly to collect data and information which includes assets, liabilities, capital, income, and costs, as well as the amount the cost of acquisition and delivery of goods/services, which is closed by compiling a report financial statements in the form of balance sheets and income statements for the tax year period. The financial report must be attached to the submission of the annual SPT in accordance with with Article 4 paragraph (4), (4a), (4b) UU KUP (Ramadhan, Adiyanta, \& Sa'adah, 2021).

Meanwhile, according to the KUP Law Number 16 of 2009 Article 28 paragraph (9), recording is regular collection of data on gross turnover and or gross income Knowledge of Accounting and Tax as the basis for calculating the amount of tax payable, including income earned not a tax object and/or subject to final tax (Rizqy, 2013). 
Based on the above background, the authors are interested in discussing this article with the title "The Importance of Agency SPT and MSME Development Strategies in Parungpanjang Regency".

\section{Research Theory}

The Indonesian Institute of Accountants (IAI) has issued Standards for the Preparation of Entity Financial Statements Without Public Accountability (SAK ETAP) on 17 July 2009 and effective as of 1 January 2011. SAK ETAP intended for small scale companies such as MSMEs to facilitate small business actors in prepare their own financial reports. Financial reports according to SAK ETAP include; balance sheet, income statement loss, statement of changes in capital, statement of cash flows and notes to financial statements.

According to (Rahmayeli \& Marlius, 2017) report financial statements consist of a balance sheet, income statement and statement of changes in capital, the three components of the report The financial statements can already reflect the financial condition of a business unit. The balance sheet is a financial statement that shows the company's financial position as of certain (Teori \& Aksara, 2016). The financial position in question is the amount and type of assets (assets) and liabilities (liability and capital). While the income statement is a report prepared to describe the results company for a certain period. The income statement relates to revenues and expenses that are issued by the company for a period. The statement of changes in capital is a report that shows the causes of changes in capital after adding profits or deducting losses.

According to (Wahyudiono, 2014) explains that the report on changes in capital is a report that explains changes in owner's capital over the long term certain time

\section{Taxes}

According to (Wahyudiono, 2014) states that the definition of Mandatory Taxes are Individuals or Entities, including taxpayers, withholders tax collectors, and tax collectors, who have tax rights and obligations in accordance with the provisions of the tax laws and regulations. According to (Resmi, 2013) Taxpayers are Individuals or Entities, including taxpayers, tax cutters, and tax collectors who have the right and tax obligations in accordance with the provisions of laws and regulations.

Taxpayers according to (Halim, Bawono, \& Dara, 2014) stated that: "Taxpayers are Individuals or Entities, including payers" tax collectors, tax cutters, and tax collectors who have the right and tax obligations in accordance with the provisions of the regulations legislation."

According to (Mardiasmo, 2016), the definition of an individual is: "People who reside or are in Indonesia more than 183 days in a 12 month period and in a tax year are in Indonesia and have the intention of residing in Indonesia." 
Meanwhile, according to (Erly Suandy, 2011) ndividual Taxpayers (WPOP) is an individual who, according to statutory provisions, taxation is determined to carry out tax obligations including: certain tax collectors or withholding tax. Based on the definition of Individual Taxpayer (WPOP) from the experts above, the author synthesizes that the number of Individual Taxpayers (WPOP) is an individual taxpayer who is domiciled and domiciled in Indonesia that has been registered at the designated tax service office by law to carry out their tax obligations including; collect, report and pay taxes owed.

\section{Research Methods}

\section{a. Types of research}

This research is a research using descriptive method, namely with training and policy assistance in managing good cash flow. The training and mentoring that we provide is by providing training on the preparation of the company's budget, and assistance in managing the company's receivables and assistance and training in the management of company debt. Our hope is that the company can manage its finances effectively and efficiently. In this research, the observation period is $2020-2021$ (Purnamawati, 2018).

\section{b. Method of collecting data}

The data collection method used in this study is a quantitative and descriptive method, namely by reviewing, researching, and providing training and guidance to companies in recording transactions and making annual and periodic tax returns. Thus making the company more effective and efficient in dealing with financial reporting and tax reporting issues (David, Dube, \& Ngulube, 2013).

\section{c. Research Object}

This research was conducted on UMKM-IKM Parungpanjang District which is engaged in the culinary field and has the hope of continuing to develop to advance / improve UMKM- IKM in the culinary field.

\section{d. Data source}

The source of the data obtained for this research is from manual data collection provided by the UMKM-IKM district. Parung Panjang against us. From the source of the data obtained, Mentoring makes Annual and Periodic SPT by way of direct practice by the finance department, after inputting the collected data or data in manual form, then the next process is to see the report on the results of the input process. This assistance will make it easier for companies to report taxes (Purnamawati, 2018).

\section{Results and Discussions}

\section{Research result}

The results obtained from this community service are as follows:

1) Companies in carrying out accounting records have been using manuals with excel in recording and making financial reports.

2) After gaining knowledge about taxation, the company is committed to reporting and paying taxes according to applicable regulations. 
3) After discussing and consulting on tax issues being faced by the company, these problems began to get clarity and bright spots to be continued at the next stage.

\section{Discussion}

1) In making Annual and Periodic SPT, the company is still constrained in preparing the Company's financial statements so that the company is still having trouble making Annual and Periodic SPT. Servant lecturers provide knowledge related to taxation and how to make Annual and Periodic Tax Returns.

2) The UMKM-IKM Forum is an UMKM engaged in the catering business. In recent years the company has experienced problems in preparing financial statements and tax reporting caused by the lack of human resources in the accounting and tax fields. This has resulted in the company not yet depositing and reporting 2019 taxes. Servant lecturers provide assistance in the preparation of Annual and Periodic SPTs and provide input related to tax issues faced by the Company. from collecting transaction evidence, preparing financial statements and tax reporting.

3) The initial stage carried out by the service team was introducing taxes, filling out annual and periodic tax returns, the next stage providing assistance in filling and making annual and periodic tax returns.

\section{Conclusion}

Efforts made by the service team as Pamulang University lecturers to increase knowledge about Assistance in Making Annual and Periodic SPTs at the MSME-IKM Forum that are useful for themselves and others, especially for companies, are by providing community service by providing counseling and assistance. Thus, the employees of the MSME-IKM Forum can implement the knowledge they have gained in Assistance in Making Annual and Periodic SPTs. this can provide input and new knowledge in Reporting in accordance with the applicable Taxation Law.

Benefits of Assistance in Making Annual and Periodic SPTs so that they are able to know the Making of Annual and Periodic SPTs regarding the importance of financial reports in companies that are useful in seeing the company's performance as seen from financial reporting every year, and how much tax must be reported. 


\section{BIBLIOGRAFI}

David, Rodreck, Dube, Adock, \& Ngulube, Patrick. (2013). A cost-benefit analysis of document management strategies used at a financial institution in Zimbabwe: A case study. South African Journal of Information Management, 15(2), 1-10.Google Scholar

Erly Suandy. (2011). Perencanaan Pajak, Edisi 5. Jakarta: Salemba Empat.

Halim, Abdul, Bawono, Icuk Rangga, \& Dara, Amin. (2014). Perpajakan: Konsep, Aplikasi, Contoh, dan Studi Kasus. Jakarta: Salemba Empat. Google Scholar

Lita, Helza Nova, \& Murwadji, Tarsisius. (2019). Implementation of Corporate Social Responsibility (Csr) In Indonesia Sharia Banking Through the Assistance of Small and Medium Enterprises. Revista Publicando, 6(19), 132-143. Google Scholar

Mardiasmo. (2016). Perpajakan Edisi Revisi Tahun 2016. Yogyakarta: Penerbit Andi. Google Scholar

Purnamawati, I. Gusti Ayu. (2018). Green Accounting: A Management Strategy and Corporate Social Responsibility Implementation. International Journal of Community Service Learning, 2(3), 149-156. Google Scholar

Pye, Lucian W. (2015). Communications and Political Development.(SPD-1). Princeton University Press.

Rahmayeli, Dina Septi, \& Marlius, Doni. (2017). Analisis Kinerja Keuangan Pada PT. Bank Perkreditan Rakyat (BPR) Batang Kapas Pesisir Selatan. Google Scholar

Ramadhan, Mirza, Adiyanta, F. C. Susila, \& Sa'adah, Nabitatus. (2021). Google AdSense Publisher Taxation Obligation.Google Scholar

Resmi, Siti. (2013). Perpajakan; Teori dan Kasus. Google Scholar

Rizqy, Mutia. (2013). Evaluation Of Fiscal Correction Based On Income Tax Act No 36 Year 2008, Study Case At Pt. X. President University. Google Scholar

Scheer, August Wilhelm. (2012). Business process engineering: Reference models for industrial enterprises. Springer Science \& Business Media. Google Scholar

Teori, Kasus, \& Aksara, Bumi. (2016). keuangan dan implikasinya pada nilai perusahaan manufaktur. E-Jurnal Akuntansi Universitas Udayana 7 (1): 107 121.[3] Tan, Anita Prastika (2018) Pengaruh Struktur Modal, Pertumbuhan Penjualan, Profitabilitas, Ukuran Perusahaan Dan Kebijakan Deviden Terhad. Jurnal Akuntansi Universitas Udayana, 7(1), 107-121. Google Scholar 
Socialization of the Importance of the Agency's SPT Strategy and Development UMKM Strategy in Parungpanjang District

Wahyudiono, Bambang. (2014). Mudah membaca laporan keuangan. Jakarta: Raih Asa Sukses, 2014, 26-90. Google Scholar

\section{Copyright holder:}

Hidayatul Mu`Arifin, Siti Ratna Sari Dewi, Iin Rosini (2021)

First publication right:

Syntax Idea

This article is licensed under:

(c) 